\title{
Livestock as a potential biological control agent for an invasive wetland plant
}

Invasive species threaten biodiversity and incur costs exceeding billions of US\$. Eradication efforts, however, are nearly always unsuccessful. Throughout much of North America, land managers have used expensive, and ultimately ineffective, techniques to combat invasive Phragmites australis in marshes. Here, we reveal that Phragmites may potentially be controlled by employing an affordable measure from its native European range: livestock grazing. Experimental field tests demonstrate that rotational goat grazing (where goats have no choice but to graze Phragmites) can reduce Phragmites cover from 100 to $20 \%$ and that cows and horses also readily consume this plant. These results, combined with the fact that Europeans have suppressed Phragmites through seasonal livestock grazing for 6000 years, suggest Phragmites management can shift to include more economical and effective topdown control strategies. More generally, these findings support an emerging paradigm shift in conservation from high-cost eradication to economically sustainable control of dominant invasive species. 
2 Livestock as a Potential Biological Control Agent for an Invasive Wetland Plant

3 Brian R. Silliman ${ }^{1,2}$, Thomas Mozdzer ${ }^{3}$, Christine Angelini ${ }^{4}$, Jennifer

4 E.Brundage ${ }^{5}$, Peter Esselink ${ }^{6,7}$, Jan P. Bakker ${ }^{6}$, Keryn B. Gedan ${ }^{8}$, Johan van de 5 Koppel ${ }^{6,9}$, Andrew H. Baldwin ${ }^{5}$

61 Division of Marine Science and Conservation, Nicholas School of the 7 Environment, Duke University, Beaufort NC 28516

$8 \quad 2$ corresponding author

9 32Department of Biology, Bryn Mawr College, Bryn Mawr, PA 19010

$10{ }^{4}$ Department of Environmental Engineering, University of Florida, Gainesville, 11 FL 32608

$12{ }^{5}$ Department of Environmental Science and Technology, University of 13 Maryland, College Park, MD 20742

$14{ }^{6}$ Community and Conservation Ecology, University of Groningen, PO Box 15 11103, 9700 CC Groningen, The Netherlands

16 'PUCCIMAR Ecological Research and Consultancy, Boermarke 35, 9481 HD 17 Vries, The Netherlands

$18{ }^{8}$ Department of Biology, University of Maryland, College Park, MD 20742

19 'Spatial Ecology Department, Royal Netherlands Institute for Sea Research 20 (NIOZ), PO Box 140, 4400AC, Yerseke, The Netherlands; 
21 Abstract: Invasive species threaten biodiversity and incur costs 22 exceeding billions of US\$. Eradication efforts, however, are nearly 23 always unsuccessful. Throughout much of North America, land 24 managers have used expensive, and ultimately ineffective, 25 techniques to combat invasive Phragmites australis in marshes. 26 Here, we reveal that Phragmites may potentially be controlled by 27 employing an affordable measure from its native European range: 28 livestock grazing. Experimental field tests demonstrate that 29 rotational goat grazing (where goats have no choice but to graze 30 Phragmites) can reduce Phragmites cover from 100 to $20 \%$ and that 31 cows and horses also readily consume this plant. These results, 32 combined with the fact that Europeans have suppressed Phragmites 33 through seasonal livestock grazing for 6000 years, suggest 34 Phragmites management can shift to include more economical and 35 effective top-down control strategies. More generally, these findings 36 support an emerging paradigm shift in conservation from high-cost 37 eradication to economically sustainable control of dominant invasive 38 species. 
39 Introduction: Invasive species globally threaten biodiversity and, in the 40 United States alone, incur costs to human economies estimated to exceed

41120 billion US\$ each year (Pimentel et al. 2005). Controlling the spread and 42 reducing the impacts of invasive species are therefore foundational 43 objectives of conservation science and policy (Kareiva and Marvier 2011). 44 Historically, eradication of invasive species has been an ideal goal of 45 management programs, but this has rarely been achieved on ecologically 46 relevant spatial or temporal scales (Kettenring and Adams 2011). In the 47 majority of cases, complete and permanent removal of these species is 48 simply unrealistic (Sax et al. 2005). Consequently, the objectives of invasive 49 species' management are being recast to prioritize control and mitigation, 50 rather than elimination, of invasive species' impacts. In addition, 51 conservation groups are becoming increasingly focused on finding solutions 52 that not only achieve their goals but also bolster local economies (Kareiva 53 and Marvier 2011). Win-win synergisms of this type, however, are rare. To 54 ensure long-term efficacy of control-oriented programs, management 55 strategies should be tailored to both local habitat requirements (i.e., duration, 56 frequency and intensity of control measures) and community needs. 57 Invasive plants that form expansive monocultures are often key targets 
58 for management due to the direct, and usually negative, impact they have on

59 ecosystem structure, function, and services (e.g., cordgrass: Neira et al.

60 2006, crested wheatgrass: Christian and Wilson 1999, reed canary grass:

61 Lavergne and Molofsky 2004, Japanese stiltgrass: Flory and Clay 2010). In the

62 United States, control of invasive plants has been attempted through

63 herbicide application, mechanical removal (e.g., mowing, burning,

64 excavation), or biological control programs that are often costly to

65 implement, difficult to sustain over sufficient timescales, or may result in

66 unintended, harmful consequences (e.g., spillover of herbicides, non-target

67 impacts of arthropod control agents, landscape damage; see Kettenring and

68 Adams 2011 for review). In Europe, however, farmers have been culling

69 (whether intentionally or not) similarly 'invasive' plants long before such

70 modern control techniques by deploying livestock to feed on dense

71 vegetation. Grazing by large-bodied domestic herbivores, such as cows,

72 horses, sheep, and goats, cannot only be effective in suppressing dominant

73 plants (Esselink 2002), but can also result in reciprocal positive effects for

74 humans by generating valuable goods, including meat, milk, leather, and

75 wool to support local economies. In the United States, use of livestock to

76 control invasive species has been largely restricted to terrestrial grasslands

77 where this method has met with mixed success (e.g., DiTomasso 2000, Reiner

78 and Craig 2011, but see Marty 2005 and Tesauro and Ehrenfeld 2007 for

79 wetlands). Low species richness and discrete plant zonation exclusive to

80 wetland ecosystems may allow for greater success and targeted control of

81 invasive plants by livestock. New evidence from North American and 
82 European marshes, which we document below, coupled with prior research

83 on long-term grazing impacts on plant distribution in Europe, suggest that

84 livestock can be a cost-effective tool for managing the impacts and spread of

85 monoculture-forming invasive plants in wetlands, where monoculture-forming

86 invasive plant species are common and drive large-scale ecosystem change

87 (Zedler and Kercher 2004).

$88 \quad$ Under natural field settings, there is broad support for the ability of

89 herbivores to suppress invasive plant success. Specifically, herbivores can

90 reduce invasion success by limiting both invasive plant establishment and

91 performance (Levine et I 2004), with generalist native herbivores strongly

92 suppressing invasive plants (Parker et al 2006, Morrison \& Hay 2011).

93 Invasive herbivores, on the other hand, have opposite effects and can

94 facilitate invasions by reducing the abundance of native species (Parker et al

95 2006). This suggests that co-evolution/exposure of both herbivore and

96 autotroph are important considerations when choosing an appropriate

97 biocontrol agent. A novel management approach to maximize potential for

98 success would attempt to control an invasive plant with an introduced

99 herbivore (e.g. domestic livestock) that have a demonstrated effect in

100 controlling the plants in their native range.

101

In Eastern North American marshes, the common reed, Phragmites

102 australis (Cav.) Trin. ex Steud. has invaded with unrelenting success since its

103 cryptic introduction during the $18^{\text {th }}$ century from Europe (Chambers et al

104 1999, Saltonstall 2002). Phragmites, which reaches average heights of $>3 \mathrm{~m}$

105 and generates dense layers of lignified litter, outcompetes native plants for 
106 light and often forms expansive, towering monocultures (Bertness et al 2002,

107 Silliman and Bertness 2004, Meyerson et al. 2012). Introduced Phragmites is 108 particularly successful in marshes along developed shorelines (Bertness et al.

109 2002, Silliman and Bertness 2004, King et al. 2007), and its rate of invasion is

110 likely to increase in the future with predicted increases in anthropogenic $\mathrm{N}$

111 pollution and rising $\mathrm{CO}_{2}$ concentrations (Bertness et al 2002, Mozdzer et al

112 2010, Mozdzer and Megonigal 2012, Mozdzer et al 2013). Where Phragmites

113 has become established, native plant diversity declines precipitously

114 (Silliman and Bertness 2004), ecosystem processes such as nitrogen cycling,

115 methane emissions, and accretion change (e.g., Rooth et al. 2003, Windham

116 \& Ehrenfeld 2003, Mozdzer \& Megongial 2013), and once-expansive marsh

117 vistas become obfuscated by this impenetrable grass.

118 The control of Phragmites has dominated marsh conservation efforts in

119 the Northeastern US for the past 30 years (Hazelton et al. 2014). During this

120 time, no cost-effective, long-term control measures have been found. For

121 example, land managers and private organizations have treated over 80,000

122 hectares of marsh with herbicide over the past five years with limited

123 success, despite costs that exceed $\$ 4.6$ million per year (Martin and Blossey

124 2013). Similarly, mechanical removal techniques, such as mowing and

125 burning, have proven to be uneconomical, given their high labor costs, and

126 ineffective (Lee 1990, Cowie et al. 1992). While insect biocontrol has been

127 investigated (Tewksbury et al. 2002, van Driesche et al. 2002), and specific

128 biocontrol agents tested in laboratory conditions (e.g. Lambert et al. 2007), it

129 is currently not an option available to land managers, in part because some 
prospective control agents do greater damage to native strains of Phragmites

131 than the invasive (e.g. Lambert et al. 2007).

132 As a facultative halophyte, Phragmites distribution is largely restricted

133 by salinity in Europe and North America. Phragmites salinity tolerance may 134 exceed normal seawater ( $33 p p t)$ (Chambers et al 2003), but its

135 competitiveness increases with decreasing salinity in the high marsh

136 elevations associated with freshwater seepage or in naturally brackish

137 wetlands (Minchinton and Bertness 2003). However, within brackish marshes

138 in Europe, Phragmites abundance is markedly limited. For instance, in the $139400-\mathrm{km}^{2}$ salt marshes of the Wadden Sea, Phragmites accounts for only $2.5 \%$ 140 of vegetation coverage (Esselink et al 2009), a significant decrease from its

141 historical extent. Although nutrient pollution has been attributed to

142 Phragmites die back in Europe (van der Putten 1997), two primary reasons

143 likely account for Phragmites' reduced distribution in European brackish

144 marshes: (1) seawall construction and land reclamation during the Middle

145 Ages (c. A.D. 1000 - 1300), which caused major loss of brackish marshes with

146 Phragmites (Schoute 1984) and (2) an extended history of livestock grazing

147 in these marshes. For example, along the brackish coast of the microtidal

148 Baltic, reed beds dominated by Phragmites were transformed into salt

149 meadows from c. 4000 B.C. onwards, when human exploitation started

150 (Vestergaard 1998). Likewise, in the Netherlands, marshes have been used as

151 rangelands since Late Neolithic, i.e. 3500 B.C. (Zeiler 2006). In these heavily

152 grazed European marshes, Phragmites is rare, but in areas where livestock

153 grazing has been abandoned in recent times, Phragmites has become 
154 dominant again (Dijkema 1990, Jutila 1999, Esselink et al. 2002, 2009). A

155 recent study confirmed these observational results: specifically, in marshes

156 still grazed by livestock, Phragmites has increased in relative abundance

157 inside grazer exclusion cages but not in control, grazed areas (Milotic et al.

158 2010, Esselink unpub. data). It is unclear whether similar top-down control

159 methods would be effective in mitigating the impacts of introduced

160 Phragmites in North America, and, if so, which large grazers and deployment

161 strategy would result in an ecologically effective and economically

162 sustainable solution for both land managers and farmers.

163 Based on observational and experimental evidence revealing that top-

164 down forces limit Phragmites in its native range in Europe, we explored the

165 potential for livestock control of invasive Phragmites in North America, and,

166 reciprocally, the nutritional benefit of Phragmites to livestock consuming it.

167 Our specific objectives were: 1) to evaluate the ability of caged livestock to

168 control invasive Phragmites and increase plant biodiversity in a small-scale

169 experimental setting, 2) to test if various commercially reared livestock

170 breeds will readily consume Phragmites, and 3) to investigate the nutritional

171 value of Phragmites as livestock forage.

172 We tested the potential for livestock to control introduced Phragmites

173 with a goat inclusion field experiment in a Phragmites-invaded North

174 American marsh. As top-down control of invasive plants by free-ranging

175 livestock can be hindered by alternative grazing options that could be

176 superior in quality (Belovsky 1986, Vulink and Drost 1991a, Vulink 2001), we

177 chose to conduct a pressed, grazing experiment in a marsh already 
178 dominated by Phragmites. To evaluate the potential of additional top-down

179 control agents besides goats and the nutritional benefits of Phragmites to 180 livestock, we conducted no-choice feeding trials with cows and horses and,

181 using data from past, unpublished studies, assessed whether livestock can 182 digest Phragmites effectively and if Phragmites nutritional quality varies 183 significantly over a growing season.

Methods: To experimentally test the hypothesis that livestock can 185 suppress Phragmites monocultures in North American marshes and promote 186 the recovery of native plants, we established randomly located replicated $187(n=4)$ goat enclosures $(8.5 \mathrm{~m} \times 40 \mathrm{~m})$ made out of wire fencing, a single188 strand of electrical wire, and metal stakes in a Phragmites-dominated 189 freshwater marsh in the Beltsville Agricultural Research Center in Beltsville, 190 Maryland, USA. Two domestic goats (IACUC number 103453) were stocked in 191 each of the enclosures (a stocking rate of 58.8 goats/ha), which were paired 192 with ungrazed control plots (also $8.5 \mathrm{~m} \times 40 \mathrm{~m}$ ) for three treatment periods of 193 2-4 weeks, beginning mid September 2008, late May 2009, and late August

194 2009. Two goats per enclosure were used because, first, goats are social

195 animals and solitary confinement might alter their well-being and grazing 196 behavior, and second, because $>2$ goats would result in too rapid 197 consumption of available plants for grazing (pers. Comm., W.Hare, 198 Veterninarian, USDA Beltsville Agricultural Research Center). Goats were left 199 in enclosures until Phragmites was completely consumed within at least one 200 of the four enclosures to maximize the duration of grazing and preventing 
201 starvation of goats. Phragmites was allowed to re-sprout and grow to a height 202 of about $1.5 \mathrm{~m}$ before applying the next round of grazing. This approach was 203 implemented to allow potential colonization of native plants and maximize 204 depletion of belowground resources of Phragmites (i.e., a level of grazing 205 pressure in excess of that typical of standard rotational grazing practices was 206 intended)Phragmites stem density and height of the five tallest stems were 207 measured before and after each grazing period in four $1-\mathrm{m}^{2}$ quadrats spaced 208 systematically at $4,8,12$, and $16 \mathrm{~m}$ along the center line of each grazed and 209 control plot (total $=32$ quadrats). Percent cover and plant species richness 210 and diversity were determined in a $100-\mathrm{m}^{2}(5 \mathrm{~m} \times 20 \mathrm{~m})$ "module" centered 211 within each grazed and control plot (Peet et al. 1998; Gurevich et al. 2006). 212 Plants that were seedlings or lacking flowering or fruiting material, but that 213 could be distinguished as separate species, were identified as 214 "morphospecies" and used in calculations of richness and diversity. Nativity 215 (native or introduced) was determined using the USDA PLANTS database for 216 plants identified to species level, or for taxa where all species were native or 217 introduced. Comparisons between grazed and ungrazed plots were made 218 using mixed model repeated measures ANOVA $(n=4)$ using the MIXED 219 procedure of SAS 9.2 (SAS Institute, Cary, North Carolina), with each pair of 220 grazed and ungrazed plots treated as a block, after checking assumptions of 221 homogeneity of variances and normality. Stem density and stem height from 222 the four $1-\mathrm{m}^{2}$ quadrats within each plot were averaged to generate a single 223 value for each grazed and control plot prior to analysis. Simple effect slices 224 were used to test for significant grazing effects for each sampling date, and 
225 the Kenward-Roger method used to calculate denominator degrees of

226 freedom (which can result in fractional ddf).

227 To explore whether Phragmites could be restricted by other domestic

228 livestock species in addition to goats, we conducted no-choice feeding trials

229 in August of 2011 with freshly cut $30-\mathrm{cm}$ sections of Phragmites stems and

230 leaves from established reed stands ( $>2 \mathrm{~m}$ in diameter). To do so, we offered

231 a 30-cm section of Phragmites stem to 20 individual horses and cows and

232 counted the number of individuals who fully consumed the section after 30

233 seconds.

234 To explore the nutritional quality of Phragmites relative to five other 235 common marsh plants, we present data here from a past, unpublished study 236 that asked this question and measured temporal variation in leaf quality of 237 six marsh plants over a growing season. Specifically, both crude-protein and 238 energy content were assessed based on sampling of the top five leaves of 239 each species at each sampling date. Samples with a fresh weight of $>200-$ $240300 \mathrm{~g}$ were collected every 3-4 weeks throughout the 1992 grazing season 241 ( end of May - mid September) from a brackish salt marsh in Dollard Bay $242\left(53^{\circ} 16^{\prime} \mathrm{N}, 7^{\circ} 10^{\prime} \mathrm{E}\right)$, the Netherlands (Marsh Section 3 of the study area in 243 Esselink et al. 2000). Crude protein content was calculated by multiplying the 244 nitrogen content by a factor 6.25 (Allen 1989). The in-vitro digestible dry 245 matter content (DDM) was used as parameter for the energy content of the 246 plant material from the animal perspective. DDM was measured according to 247 Tilley and Terry (1963). 
Results: By the end of our livestock enclosure experiment, goats had

249 strongly suppressed Phragmites growth, reducing stem density by $\sim 50 \%$ ( 29

250 to 14 stems $\mathrm{m}^{-2}$; Fig. 1a), stem height by $\sim 60 \%$ ( 3.9 to $1.4 \mathrm{~m}$; Fig. $1 \mathrm{~b}$ ), and

251 percent cover five-fold (from 94\% to $21 \%$; Fig. 1c). In grazed plots,

252 Phragmites resprouted from rhizomes or colonized from adjacent ungrazed

253 plots, but never attained the stem density, height, or cover of that in

254 ungrazed plots, except in spring of the second growing season during early

255 shoot emergence (Fig. 1). Concomitant with the strong decline of Phragmites

256 was a marked and significant increase in plant species richness and Shannon-

257 Weiner diversity index by the end of the experiment ( $100 \% \& 400 \%$

258 respectively, Fig. $2 a, b)$. At the end of the experiment, goat-grazed plots

259 contained a total of 36 taxa ( 22 confirmed native species, 8 indeterminate,

260 and 6 introduced taxa), while ungrazed plots contained only 20 taxa (12

261 native species. 2 indeterminate, and 6 introduced taxa), all of which were at

262 low abundance relative to Phragmites. Important native species that

263 colonized (from seeds in the seed bank or dispersed to the site) included

264 Alisma subcordatum, Epilobium coloratum, Leersia oryzoides, Mimulus

265 ringens, Penthorum sedoides, Polygonum punctatum, and Ranunculus

266 sceleratus. A complete list of species found in grazed and ungrazed plots is

267 included in Table S1.

268 In our no-choice feeding trials, both horses and cows readily ate

269 Phragmites (20 out of 20 individuals for both species ate the $30 \mathrm{~cm}$ stem

270 section offered). In comparison with five other marsh plant species,

271 nutritional quality of Phragmites was intermediate (Figure 3a). It must be 
272 noted that North American introduced Phragmites was introduced from

273 Europe, and we do not expect there to be any differences in tissue quality.

274 Plants described in Figure 3a have congeneric representation in North

275 American wetlands, and serve as our proxy for comparable nutritional quality.

276 Throughout the 4-month grazing season in the Dollard salt marshes, crude-

277 protein content in Phragmites leaves was surprisingly high. The energy 278 content of Phragmites leaves, on the contrary, was lower than in other 279 common plant species, and dropped markedly during the course of the 280 grazing season (Fig. 3b); after mid-July it fell below the level of

281 maintenance requirement for cattle (ARC 1980, Van Soest 1982). These 282 values for digestible dry matter were within the range found by a larger 283 survey of Dutch plant species palatability to cattle, which found Phragmites 284 to be an important natural forage species (Bokdam and Wallis de Vries 1992).

\section{Discussion}

Our results and those of others in Europe indicate that controlling invasive Phragmites in North America via purposeful livestock grazing has a high potential to suppress its impact on native plant communities. Our feeding trial from The Netherlands, together with evidence from livestockremoval and comparative studies in European marshes (Esselink et al 2002),

291 suggest that livestock strongly restrict Phragmites distribution and facilitate 292 the growth of shorter grasses and forbs in its native habitat. These results, in 293 combination with our goat enclosure experiment in the U.S., indicate 294 Phragmites is also likely susceptible to top-down control by livestock in 
295 Eastern North America. Furthermore, the short-term duration of our goat 296 inclusion periods ( $3,<1$ month deployments over 1 year), affordable 297 infrastructure (wire fences), and limited number of animals (2 goats per 340$298 \mathrm{~m}^{2}$ plot) needed to reduce Phragmites cover, imply that livestock has the 299 potential to offer an effective, pesticide-free solution for managers trying to 300 regulate this invasive plant, and likely other invasive plants that form vast 301 monocultures. The conclusion that goat grazing could be an economically 302 sustainable, win-win invasive plant control solution is also supported by the 303 fact that livestock can persist over short time periods (i.e. weeks to months) 304 on Phragmites-based diets without detriment to their health.

305 In invaded areas, Phragmites outcompetes native plants for light and 306 space due to its height, dense canopy, thick litter, and rapidly growing 307 rhizomes, and these advantages drive its rapid expansion and dominance 308 across marshes (Bertness et al. 2002, Silliman and Bertness 2004, Mozdzer \& 309 Zieman 2010, Minchinton, Farnsworth and Meyerson 2004, Holdredge et al.

310 2010). Our results and prior studies from Europe indicate that domestic

311 livestock can reduce the competitive advantage of Phragmites through a 312 combination of eating down or trampling live stems, breaking up the litter 313 mat, and severing rhizomes with their hooves (Turner 1987). Combined, 314 these activities can increase the light availability to native plants, reduce 315 belowground competition for nutrients, and thus provide opportunities for 316 recolonization of native plants, estuarine nekton, and even endangered

317 turtles (Angradi et al 2001, Tesauro 2002, Hunter et al 2006, Tesauro and 318 Ehrenfeld 2007, Tesauro 2002). In disrupting Phragmites growth, livestock 
319 also have the potential to reduce seed set, an important mechanism of

320 expansion of Phragmites in North America (McCormick et al. 2010). By

321 removing the primary mechanisms of Phragmites competitive exclusion (i.e.

322 its height and litter), livestock may not only facilitate recovery of native

323 plants and dependent faunal communities (e.g. invertebrates, arthropod

324 herbivores), but also restore coastal ecosystem services. However, we must

325 caution that introduction of livestock to invaded marshes in North America

326 will not lead to a complete return to the pre-invasion marsh structure.

327 Instead, we suspect that an alternative state will be induced (Hobbs \& Norton

328 1996). Such an alternative state may be characterized by a reduced

329 Phragmites dominance and an increased abundance of native plants and

330 fauna. Livestock grazing, however, is not without its own effects on

331 ecosystem characteristics, affecting soil bulk density, soil organic matter,

332 mineralization rate (Schrama et al. 2013), invertebrate abundance, and

333 others. Comparative, multi-year trials are needed to assess grazing impacts

334 and to determine the best regimen of grazers for Phragmites control,

335 ecosystem integrity, and livestock production.

336 Context-dependency of grazer control and next steps

337 Evidence from our study coupled with other livestock and large grazer

338 manipulative experiments (Tesauro 2002, Sturm 2007, URS 2005) suggest

339 that the efficacy of livestock control of Phragmites in North America will be

340 context-dependent and contingent both on the grazing regime and the

341 background cover of Phragmites. Specifically, these studies suggest that 
342 livestock can control Phragmites when its cover is high and livestock are

343 forced to graze in those areas (Fig. 4). For example, when Phragmites is

344 dominant and grazers are enclosed in these areas as in our experiment and a

345 2-year study in New Jersey, USA that manipulated goats and sheep in small

346 (0.8 ha), un-replicated pens (Tesauro 2002), livestock were effective at

347 reducing Phragmites from $\sim 100 \%$ to $<50 \%$ cover. In contrast, when

348 Phragmites is uncommon and livestock are free-roaming (i.e., grazers not

349 forced to eat Phragmites only), horses and deer in Maryland increased

350 Phragmites abundance relative to grazer exclusion plots (Sturm 2007).

351 Similarly, goats released into a larger ( 0.8 ha) Phragmites-invaded tidal

352 marsh in New Jersey did not reduce Phragmites cover and consumed other

353 marsh plants to a greater degree (URS 2005). These findings suggest that if

354 livestock are released into mixed marsh plant communities where alternative

355 food choices are abundant (i.e., Phragmites is uncommon) large grazers have

356 the potential to facilitate Phragmites invasion, and thus be counterproductive

357 to management objectives. This conclusion is supported by our nutritional

358 content study (Fig. 3) and those of others (e.g. Vulink \& Drost 1991b) that

359 indicate Phragmites has a lower nutritional value relative to other common

360 marsh plants and thus would not likely be preferred by grazers if given a

361 choice.

362 Based on these conclusions, we suggest preliminary guidance for

363 applications of livestock for invasive plant control (Table 1) and recommend

364 future directions for research. Our grazing experiment, in which grazing had

365 stronger effects in early summer than late summer, as well as our 
assessment of a decline in Phragmites' nutritional value through time,

367 indicate that the timing of grazer implementation may be critical for the

368 success of livestock control programs as young stems have higher nutritional

369 quality (Fig 3) and grazing on young Phragmites' stems in early spring is

370 more effective at reducing future regrowth and promoting native plant

371 recovery (Karunaratne et al 2004). Future research should address whether

372 springtime or early summer grazing has stronger impact on Phragmites and

373 other monoculture forming invasive plants. Looking forward, the next step in

374 determining the potential for livestock to control_Phragmites and facilitate the

375 recovery of native plants, animals and pre-invasion soil properties is to test

376 these ideas at larger scales and over multiple years to compare to reference

377 wetlands without grazer control of invasive plants and those using other

378 invasive species control techniques.

Finally, prior to application, it is critical to investigate the potential for

380 livestock grazing impacts on non-target organisms and ecosystem processes.

381 Decisions about the placement and timing of grazers should incorporate local

382 site knowledge to avoid priority seasons and habitat areas for nesting birds

383 and other possibly sensitive taxa or conservation targets. Further research

384 could also identify the effects of short periods of grazing on critical wetland

385 ecosystem processes such as soil compaction and surface elevation

386 accretion, and examine the possibility that invasive plant seeds remain viable

387 during livestock gut passage and are unwittingly dispersed to other sites.

$388 \quad$ Although inter-site variation and inter-annual differences make the

389 synthesis of experimental findings from different decades and continents 
difficult, we find the consistent palatability of Phragmites to a diverse set of

391 commercially important grazers in Europe and North America inspiring to

392 pursue livestock grazing as a invasive species management tool. Other

393 effective methods may be found by looking across ecosystems and

394 continents for scenarios where dominant plants, whether purposefully or not,

395 are being controlled using measures that involve and benefit local

396 communities.

397 For monoculture-forming plants invading softer, lower elevations of 398 marshes, such as Spartina alterniflora, on the West Coast of the US and China 399 or Cuelerpa in soft-sediment intertidal expanses throughout the world, 400 domestic livestock are not likely an option for management. However, other 401 economically sustainable, but currently overlooked, rotational top-down 402 control methods may work for these species, such as systematic human 403 harvesting of invasive plants to be used as livestock feed or biofuel.

404 Evidence from European marshes that a top-down restoration strategy will 405 work

Restoration of coastal marshes presently dominated by Phragmites has 407 not been practiced widely in Europe, except for in the Baltics. There, a 408 comparison of uninterruptedly managed (seasonal summer grazing), 409 abandoned (no grazing) and restored (i.e., summer grazing re-introduced 410 after abandonment) sites in coastal marshes revealed that plant biomass in 411 restored sites rapidly changed back to the level of managed marshes 412 (Sammul et al 2012) and Phragmites cover decreased significantly. Plant 
413 species composition remained different, but typical coastal grassland species

414 colonized and increased in abundance in restored sites (Sammul et al. 2012).

415 The response of soil properties to the re-introduction of grazing evolved more

416 slowly. In abandoned sites for instance, organic matter content and $\mathrm{C} / \mathrm{N}$ ratio

417 were significantly higher and bulk density significantly lower than in

418 uninterruptedly managed sites. In the five-year old restored sites, however,

419 all soil variables still did not differ from abandoned sites, implying that the

420 results of grazer-driven restoration may be slow for some variables. In

421 addition, return of tall-growing Phragmites is likely if management intensity

422 wanes. Sammul et al (2012) conclude that Phragmites can indeed be

423 suppressed in sites where it is dominant, but considering the slow response

424 of soil properties, long-lasting periods of livestock-enhanced restoration

425 should be planned in order to reach pre-abandonment environmental

426 conditions.

427 Further incentives for integrating top-down control into invasive species

428 management

429 While we have specifically focused on the control of an invasive plant as a

430 management objective, this control has ancillary benefits and indirectly

431 addresses multiple conservation targets. In addition to offering a solution for

432 management of invasive plants that form expansive, hard-to-eradicate

433 monocultures, livestock control programs can have reciprocal, positive

434 impacts on local economies. Specifically, as is done in Europe, farmers could

435 potentially receive payment for their services in controlling invasive species, 
436 and resources (e.g. fencing, transportation of livestock) to engage in such

437 programs. At the same time, conservation groups and government

438 organizations will receive more cost-effective and ecologically friendly tools

439 to manage problematic invasive plants. Several instances of companies

440 offering services of goats and other livestock to control Phragmites in urban

441 wetlands in New York City, tidal wetlands in the Chesapeake Bay (e.g. Eco-

442 Goats), and riverbank wetlands in the U.S. mid-west suggest that these

443 ventures are marketable. More data are needed to confirm the short- and

444 long-term sustainability of these business models. In many arenas, win win

445 solutions of economic gains in controlling invasives are often criticized with

446 the argument that at some point the invasive species is going to be needed

447 to maintain the economic model based upon it. In our proposed scenario 448 using goat control of an invasive plant, however, we do not believe this will 449 ever be the case as goats will likely always have more invasive to graze in 450 the area (e.g. Kudzu) and, even when invasive plants have been locally 451 suppressed, goats can still provide numerous benefits to their owners (e.g. 452 dairy and meat production).

453 Beyond the target site where grazing is implemented, control of 454 Phragmites reduces propagule pressure (McCormick et al. 2010) and 455 interrupts positive feedbacks reducing spread to un-invaded sites (Hazelton 456 et al 2014). In addition, this approach provides an alternative treatment 457 option when herbicide use is unacceptable or infeasible or where reduced 458 Phragmites biomass and some native cover is an acceptable goal. 
459 This general framework, designed to link invasive species management 460 with the production of useable goods and benefit of local economies can also 461 be applied to other systems where invasive species threaten ecosystem 462 services (Tulbure et al 2007, Levin 2006). By identifying, and then harnessing 463 the positive effects of grazers, coastal managers could potentially fulfill their 464 conservation goals with significant reduction in cost. Overall, a shift in 465 invasive species management from eradication to mitigation of invasive 466 species impacts is creating opportunities for the implementation of new 467 strategies, including the use of atypical top-down control agents.

\section{Acknowledgements}

469 The manuscript benefited from comments of Sip van Wieren on an earlier 470 draft of the manuscript. 


\section{References}

472 Allen, SE. 1989. Chemical analysis of ecological materials. $2^{\text {nd }}$ Ed. Blackwell 473 Scientific Publications, Oxford. 368 pp.

474 Angradi TR, Hagan SM, Able KW. 2001. Vegetation type and the intertidal 475 macroinvertebrate fauna of a brackish marsh: Phragmites vs. Spartina. 476 Wetlands 21: 75-92.

477 ARC. 1980. The nutrient requirements of ruminant livestock. London. Report 478 no.

479 Belovsky GE. 1986. Optimal Foraging and Community Structure - Implications 480 for a Guild of Generalist Grassland Herbivores. Oecologia 70: 35-52.

481 Bertness MD, Ewanchuk PJ, Silliman BR. 2002. Anthropogenic modification of 482 New England salt marsh landscapes. Proceedings of the National Academy of 483 Sciences of the United States of America 99: 1395-1398.

484 Bokdam J, Wallis de Vries,MF 1992. Forage quality as a limiting factor for 485 cattle grazing in isolated Dutch nature reserves. Conservation Biology 6:399486408.

487 Chambers RM, Meyerson LA, Saltonstall K. 1999. Expansion of Phragmites 488 australis into tidal wetlands of North America. Aquatic Botany 64: 261-273. 
489 Chambers RM, Osgood DT, Bart DJ, Montalto F. 2003. Phragmites australis

490 invasion and expansion in tidal wetlands: Interactions among salinity, sulfide, 491 and hydrology. Estuaries 26: 398-406.

492 Christian JM, Wilson SD. 1999. Long-term ecosystem impacts of an introduced 493 grass in the northern Great Plains. Ecology 80: 2397-2407.

494 Cowie NR, Sutherland WJ, Ditlhogo MKM, James R. 1992. The effects of 495 conservation management of reed beds II. The flora and litter disappearance. 496 Journal of Applied Ecology 29: 277-284.

497 Dijkema KS. 1990. Salt and brackish marshes around the Baltic Sea and 498 adjacent parts of the North-Sea - their vegetation and management. 499 Biological Conservation 51: 191-209.

500 DiTomaso JM. 2000. Invasive weeds in rangelands: Species, impacts, and 501 management. Weed Science 48: 255-265.

502 Esselink P, Zijlstra W, Dijkema KS, van Diggelen R. 2000. The effects of 503 decreased management on plant-species distribution patterns in a salt marsh 504 nature reserve in the Wadden Sea. Biological Conservation 93: 61-76.

505 Esselink P, Fresco LFM, Dijkema KS. 2002. Vegetation change in a man-made 506 salt marsh affected by a reduction in both grazing and drainage. Applied 507 Vegetation Science 5: 17-32.

508 Esselink P, Petersen J, Arens S, Bakker JP, Bunje J, Dijkema KS, Hecker N, 509 Hellwig U, Jensen AV, Kers AS, Körber P, Lammerts EJ, Lüerssen G, Marencic

$510 \mathrm{H}$, Stock M, Veeneklaas RM, Vreeken M, Wolters M. 2009. Salt marshes. In:

511 Marencic H, de Vlas J (eds) Quality Status Report 2009. Wadden Sea

512 Ecosystems 25: 1-54. 
513 Farnsworth EJ, Meyerson LA. 2003. Comparative ecophysiology of four

514 wetland plant species along a continuum of invasiveness. Wetlands 23: 750-

515762.

516 Flory SL, Clay K. 2010. Non-native grass invasion alters native plant

517 composition in experimental communities. Biological Invasions 12: 1285-

5181294.

519 Gurevich J, Scheiner SM, Fox GA. 2006. The ecology of plants. Sunderland, 520 MA: Sinauer.

521 Hazelton E, Mozdzer TJ, Burdick D, Kettenring, KM, Whigham DF. 2014.

522 Phragmites australis management in the United States: 40 years of

523 management and outcomes. AoB Plants.

524 Hobbs RJ, Norton DA. 1996. Towards a conceptual framework for restoration

525 ecology. Restoration Ecology 4: 93-110.

526 Holdredge C, Bertness MD, von Wettberg E, Silliman BR. 2010. Nutrient

527 enrichment enhances hidden differences in phenotype to drive a cryptic plant

528 invasion. Oikos 119: 1776-1784.

529 Hunter KL, Fox DA, Brown LM, Able KW. 2006. Responses of resident marsh

530 fishes to stages of Phragmites australis invasion in three mid Atlantic

531 estuaries. Estuaries and Coasts 29: 487-498.

532 Jutila H. 1999. Effect of grazing on the vegetation of shore meadows along 533 the Bothnian Sea, Finland. Plant Ecology 140: 77-88.

534 Kareiva P, Marvier M. 2010. Conservation science: balancing the needs of 535 people and nature. Greenwood Village, Colorado: Roberts and Company. 
536 Karunaratne S, Asaeda T, Yutani K. 2004. Shoot regrowth and age-specific

537 rhizome storage dynamics of Phragmites australis subjected to summer

538 harvesting. Ecological Engineering 22: 99-111.

539 Kettenring KM, Adams CR. 2011. Lessons learned from invasive plant control

540 experiments: a systematic review and meta-analysis. Journal of Applied

541 Ecology 48: 970-979.

542 King RS, Deluca WV, Whigham DF, Marra PP. 2007. Threshold effects of

543 coastal urbanization on Phragmites australis (common reed) abundance and

544 foliar nitrogen in Chesapeake Bay. Estuaries and Coasts 30: 469-481.

545 Lambert, A.M., Winiarski, K., and R.A. Casagrande. 2007. Distribution and

546 impact of exotic gall flies (Lipara sp.) on native and exotic Phragmites

547 australis. Aquatic Botany 86:163-170.

548 Lavergne S, Molofsky J. 2004. Reed canary grass (Phalaris arundinacea) as a

549 biological model in the study of plant invasions. Critical Reviews in Plant

550 Sciences 23: 415-429.

551 Lee SY. 1990. Net aerial primary productivity, litter production and

552 decomposition of the reed Phragmites communis in a nature-reserve in Hong-

553 Kong - management implications. Marine Ecology Progress Series 66: 161-

554173.

555 Levin SA. 2006. Learning to live in a global commons: socioeconomic

556 challenges for a sustainable environment. Ecological Research 21: 328-333.

557 Martin, L.J. and B. Blossey. 2013. The runaway weed: Costs and failures of

558 Phragmites australis management in the USA. Estuaries and Coasts 36:626559632. 
Marty JT. 2005. Effects of cattle grazing on diversity in ephemeral wetlands.

561 Conservation Biology 19: 1626-1632.

562 McCormick MK, Kettenring KM, Baron HM, Whigham DF. 2010. Extent and

563 reproductive mechanisms of Phragmites australis spread in brackish wetlands

564 in Chesapeake Bay, Maryland (USA). Wetlands 30: 67-74.

565 Meyerson LA, Saltonstall K, Chambers RM. 2012. Phragmites australis in

566 eastern North America: a historical and ecological perspective. In Silliman BR,

567 Bertness MD, Strong D, eds. Anthropogenic Modification of North American

568 Salt Marshes.

569 Milotic T, Erfanzadeh R, Petillon J, Maelfait JP, Hoffmann M. 2010. Short-term 570 impact of grazing by sheep on vegetation dynamics in a newly created salt-

571 marsh site. Grass and Forage Science 65: 121-132.

572 Minchinton TE, Bertness MD. 2003. Disturbance-mediated competition and

573 the spread of Phragmites australis in a coastal marsh. Ecological Applications

574 13: 1400-1416.

575 Morrison WE, Hay ME. 2011. Herbivore Preference for Native vs. Exotic Plants:

576 Generalist Herbivores from Multiple Continents Prefer Exotic Plants That Are

577 Evolutionarily Naïve. PLoS ONE 6(3): e17227.

578 TJ Mozdzer, J Brisson, ELG Hazelton. 2013. Physiological ecology and

579 functional traits of North American native and Eurasian introduced

580 Phragmites australis lineages

581 AoB Plants 5, plt048. 
582 Mozdzer TJ, Megonigal JP. 2012. Jack-and-master trait responses to elevated

$583 \mathrm{CO} 2$ and N: A comparison of native and introduced Phragmites australis. Plos 584 One 7 (10): e42794.

585 Mozdzer TJ, Zieman JC, McGlathery KJ. 2010. Nitrogen uptake by native and 586 invasive temperate coastal macrophytes: Importance of dissolved organic 587 nitrogen. Estuaries and Coasts 33: 784-797.

588 Neira C, Grosholz ED, Levin LA, Blake R. 2006. Mechanisms generating 589 modification of benthos following tidal flat invasion by a Spartina hybrid. 590 Ecological Applications 16: 1391-1404.

591 Peet RK, Wentworth TR, White PS. 1998. A flexible, multi-purpose method for 592 recording vegetation composition and structure. Castanea 63: 262-274.

593 Pimentel D, Zuniga R, Morrison D. 2005. Update on the environmental and 594 economic costs associated with alien-invasive species in the United States. 595 Ecological Economics 52: 273-288.

596 Reiner R, Craig A. 2011. Conservation easements in California blue oak 597 woodlands: Testing the assumption of livestock grazing as a compatible use. 598 Natural Areas Journal 31: 408-413.

599 Rooth, J., Stevenson, J.C., and J.C. Cornwell. 2003. Increased sediment 600 accretion rates following invasion by Phragmites australis: the role of litter. 601 Estuaries 26:475-483.

602 Saltonstall K. 2002. Cryptic invasion by a non-native genotype of the 603 common reed, Phragmites australis, into North America. Proceedings of the 604 National Academy of Sciences of the United States of America 99: 24456052449. 
606 Sammul M, Kauer K, Koster T. 2012. Biomass accumulation during reed

607 encroachment reduces efficiency of restoration of Baltic coastal grasslands.

608 Applied Vegetation Science 15: 219-230.

609 Sax, D.F., Stachowicz, J.J., and Gaines, S.D., editors. 2005. Species Invasions:

610 Insights into Ecology, Evolution and Biogeography. Sinauer, Sunderland, MA.

611 Schoute JFT. 1984. Vegetation horizons and related phenomena: a

612 palaeoecological-micromorphological study in the younger coastal Holocene

613 of the northern Netherlands (Schildmeer area). Strauss and Cramer. $270 \mathrm{p.}$

614 Schrama M, Heijning P, Bakker JP, Berg MP, Olff H. 2013. Herbivore trampling

615 as an alternative pathway for explaining differences in nitrogen

616 mineralization in moist grasslands. Oecologia 172: 231-243.

617 Silliman BR, Bertness MD. 2004. Shoreline development drives invasion of

618 Phragmites australis and the loss of plant diversity on New England salt

619 marshes. Conservation Biology 18: 1424-1434.

620 Sturm M. 2007. Assessment of the effects of feral horses, sika deer and

621 white-tailed deer on Assateague Island's forest and shrub habitats. Berlin, MD

622 21811: Assateague Island National Seashore.

623 Tesauro J. 2002. The effects of livestock grazing on the bog turtle (Clemmys

624 muhlenbergii). Rutgers University, New Brunswick, NJ.

625 Tesauro J, Ehrenfeld D. 2007. The effects of livestock grazing on the bog turtle

626 [Glyptemys (= Clemmys) muhlenbergii]. Herpetologica 63: 293-300.

627 Tewksbury, L., Casagrande, R., Blossey, B., Häfliger, P., and M. Schäwrzlander.

628 2002. Potential for biological control of Phragmites australis in North America.

629 Biological Control 23: 191-212. 
630 Tilley JM, Terry RA. 1963. A two stage technique for the in-vitro digestion of

631 forage crops. Journal of the British Grassland Society 18: 104-111.

632 Tulbure MT, Ghioca DM, Whigham CA. 2007. Comparative ecology of native

633 and non-native Phragmites australis (common reed) genotypes. Society of

634 Wetland Scientists. Sacremento, CA.

635 Turner MG. 1987. Effects of grazing by feral horses, clipping, trampling, and 636 burning on a Georgia salt-marsh. Estuaries 10: 54-60.

637 URS. 2005. Phragmites control alternatives assessment report. Wayne, New 638 Jersey: Prepared for PSEG Services Corporation Estuary Enhancement

639 Program.

640 Van Driesche, R., Blossey, B., Hoddle, M., Lyon, S., Reardon, R., 2002,

641 Biological control of invasive plants in the eastern United States, USDA Forest 642 Service Publication FHTET-2002-04, 413 p.

643 Van Soest PJ. 1982. Nutritional ecology of the ruminant. Corvallis, Oregon:

644 O\&B Books Inc.

645 Vestergaard P. 1998. Vegetation ecology of coastal meadows in Southeastern 646 Denmark. Opera Botanica 134: 5-69.

647 Vulink JT. 2001. Hungry herds. Management of temperate lowland wetlands 648 by grazing. Van Zee tot Land 66: 1-385.

649 Vulink JT, Drost HJ. 1991a. Nutritional characteristics of cattle forage plants in 650 the eutrophic nature reserve Oostvaardersplassen, the Netherlands.

651 Netherland Journal of Agricultural Science 39: 263-272.

$652-.1991 b$. A causal-analysis of diet composition in free ranging cattle in reed653 dominated vegetation. Oecologia 88: 167-172. 
654 Windham L, Ehrenfeld JG. 2003. Net impact of a plant invasion on nitrogen-

655 cycling processes within a brackish tidal marsh. Ecological Applications 13:

656 883-896.

657 Windham L, Meyerson LA. 2003. Effects of common reed (Phragmites

658 australis) expansions on nitrogen dynamics of tidal marshes of the

659 northeastern US. Estuaries 26: 452-464.

660 Zedler, J.B. and S. Kercher. 2004. Causes and consequences of invasive

661 plants in wetlands: Opportunities, opportunists, and outcomes. Critical

662 Reviews in Plant Sciences, 23(5):431-452.

663 Zeiler JT. 2006. Mammals. In: Louwe Kooijmans LP, Jongste PFB, eds.

664 Schipluiden. A Neolithic settlement on the Dutch North Sea coast c. 3500 cal

665 BC. Analecta Praehistorica Leidensia 37/38: 375-420.

\section{Table 1. Management Considerations}

667 Based on our experimental findings, we find that livestock grazing for control

668 of invasive plants holds great potential to reduce invasive plant biomass,

669 increase plant diversity, and support livestock production. For effective

670 control and to avoid negative impacts of over-grazing, we recommend:

671 1. High-intensity, short-duration, rotational grazing. Grazers will be most

672 effective in dense, monotypic stands that are common in the

673 establishment and spread phases of invasions. Periods without grazers are

674 likely very important in allowing native plants to establish (Fig. 2) and for

675 the health of grazing livestock (Fig. 3b). 
676

677

678

679

680

681

682

683

684

685

686

687

688

689

690

691

692

2. Small scale enclosures to concentrate feeding on the dominant, invasive plant (Fig. 4). In the case of Phragmites, the high digestible dry matter content of other wetland plant species (Fig. 3a) suggests that livestock permitted to graze freely might prefer other available plants.

3. The incorporation of grazing into a long-term management scheme. Grazing will not eradicate an invasive plant, but will release native plants from invasive dominance temporarily. Therefore, grazing may have to occur throughout many years, and possibly indefinitely.

4. Species-specific grazing windows. Time grazing events to suppress dominant plant invaders (i.e. early in the growing season) and limit clonal regrowth while providing adequate windows for native plants recolonization.

5. Landscape considerations. Grazing is unlikely to be effective in softsediment environments, such as low elevation marshes, where trampling effects may overwhelm native plant recovery. Grazers will be most effective on firm soils, such as those in the high marsh and at the upland marsh ecotone, where Phragmites invasions begin. 
693 Figure 1. Effect of goats on three measures of Phragmites australis

694 abundance from July 2008 - October 2009. Values are mean \pm SE for 4

695 replicate enclosures (grazed) and control (ungrazed) plots. Stem density and

696 height were determined in $1-\mathrm{m}^{2}$ plots and percent cover was determined in

$697100-\mathrm{m}^{2}$ plots. Arrows indicate the initiation of grazing periods; for cover (1c),

698 the third grazing period falls between the last two measurement points.

699 Results of repeated measures ANOVA are given within each panel for effects

700 of grazing (G), date (D), and their interaction (GXD). $+P<0.1, * P<0.05$,

$701 * * \mathrm{P}<0.01, * * * \mathrm{P}<001$, and $* * * * \mathrm{P}<0.0001$. Asterisks above plotted points

702 denote a significant grazing effect for that sampling date $(P<0.05$, simple

703 effect of grazing by date); P-value given for the last stem density comparison,

704 where $\mathrm{P}$ was between 0.05 and 0.1 .

705 Figure 2. Changes in plant species richness (a) and Shannon-Weaver diversity

706 (b) throughout the experiment in response to rotational goat grazing. Values

707 are means \pm SE for 4 replicate enclosures (grazed) and controls (ungrazed).

708 Arrows indicate grazing period between sampling events; the third grazing

709 period falls between the last two measurement points. An asterisk indicates a

710 significant difference between grazed and ungrazed plots on a particular date

$711(P<0.05$, simple effect of grazing by date). Also presented are results of

712 repeated measures ANOVA for effects of grazing (G), date (D), and their

713 interaction (GxD). $* \mathrm{P}<0.05, * * \mathrm{P}<0.01, * * * \mathrm{P}<001$, and $* * * * \mathrm{P}<0.0001$ 
714 Figure 3. (A) Comparison of nutritional quality among six potential food plants 715 in the cattle-grazed Dollard salt marshes, Netherlands. Figure shows the in 716 vitro digestible dry-matter (DDM) content plotted with the crude-protein 717 content (mean $\pm S D$ ) in young leaf tissue (five top leaves) during the grazing 718 season (3rd decade of May - mid September). (B) Fall of forage quality (i.e., 719 energy content) in leaf tissue of primary shoots of Phragmites in the Dollard 720 salt marshes, Netherlands, during the grazing season based on the in vitro 721 digestible dry-matter content in leaf tissue and compared with the level that 722 cattle require for maintenance (after ARC 1980 \& Van Soest 1982).

723 Figure 4. Pictures of impacts of no-choice goat grazing in the Phragmites724 dominated experimental wetland. 
725 Figure 1.






726 Figure 2.

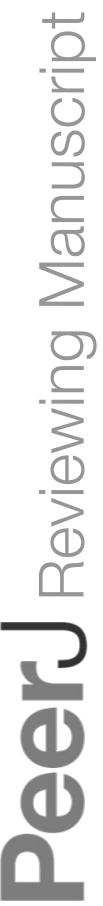






\section{Figure 3}

728 A)

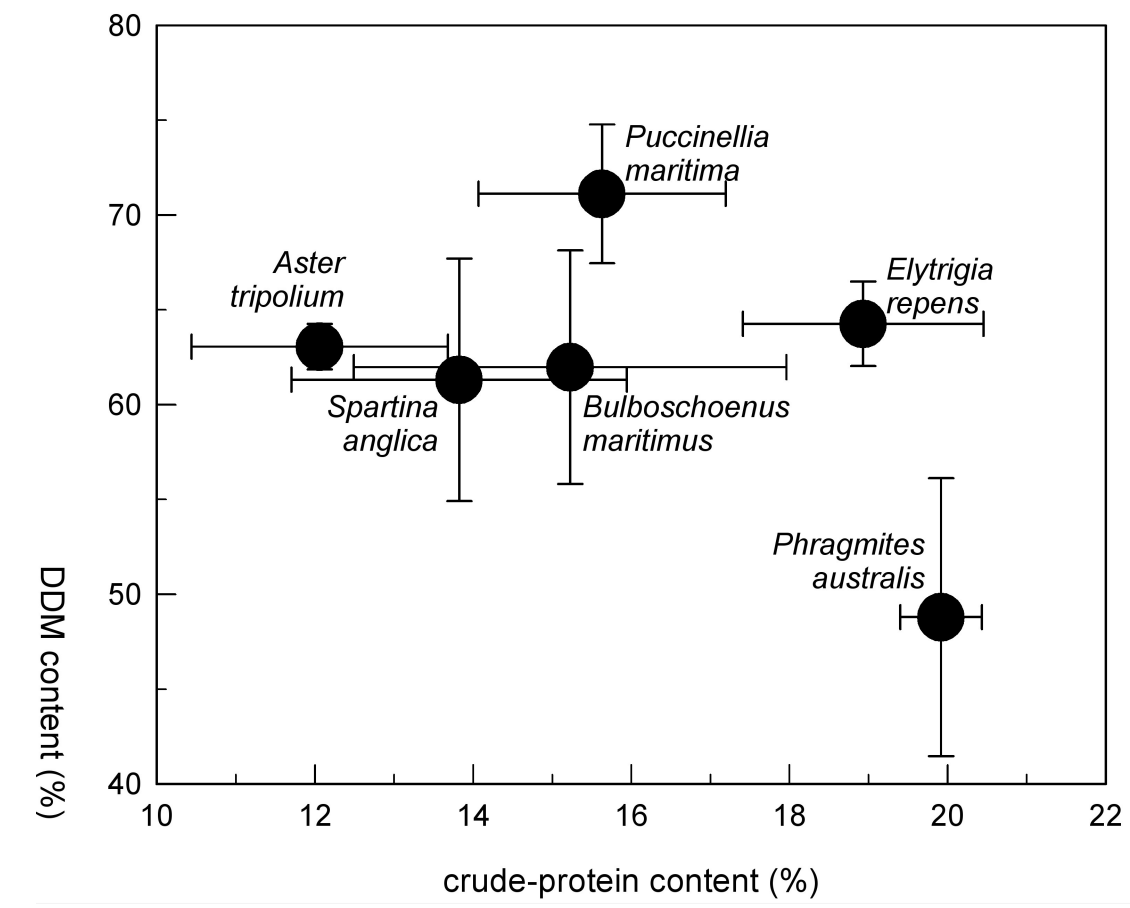

729 B) 
730 Figure 4.

$731 \quad$ A)



$732 \quad$ B)

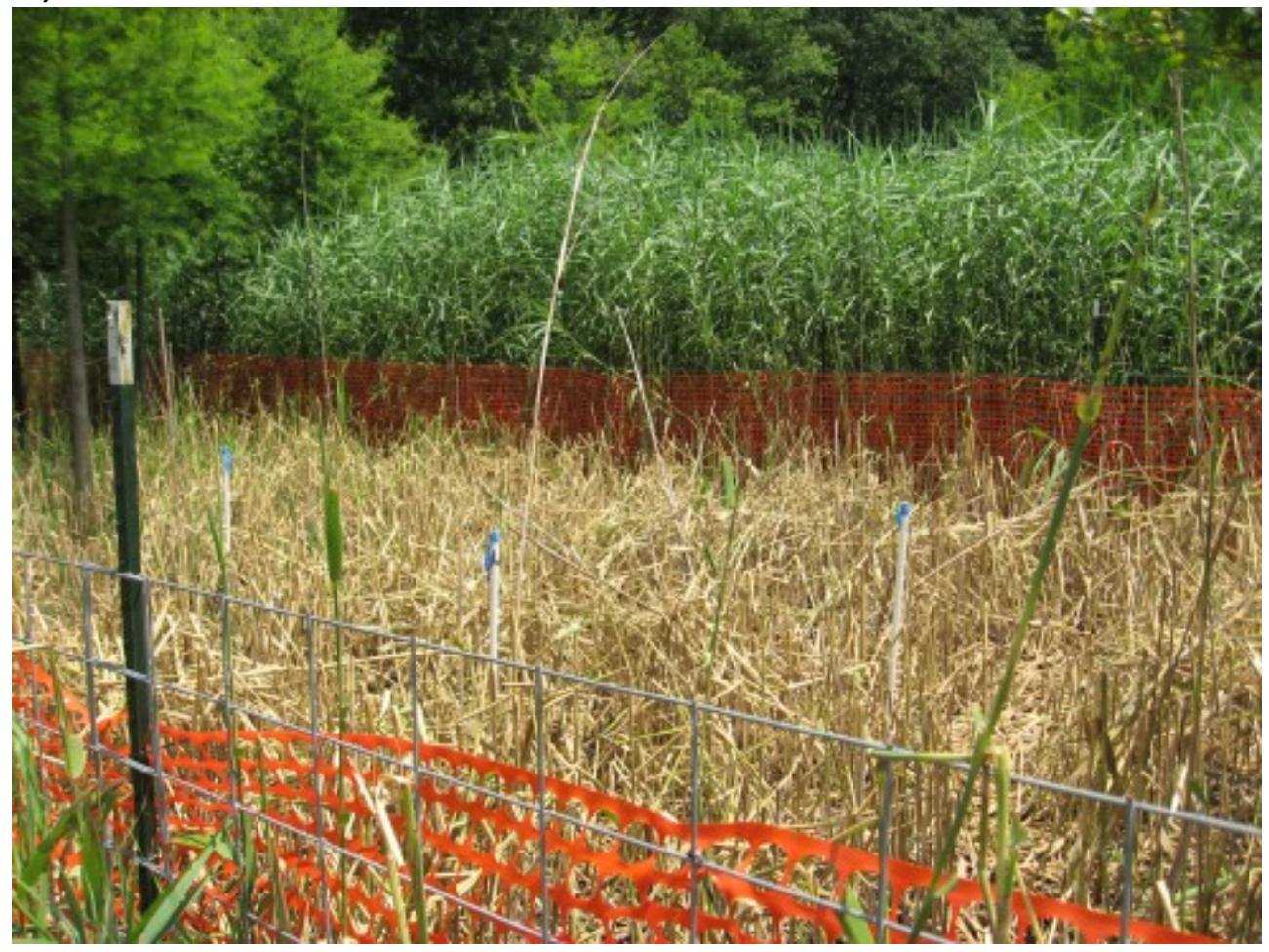




\section{Figure 1}

Goat Grazing Impacts on Phragmites

Figure 1. Effect of goats on three measures of Phragmites australis abundance from July 2008 - October 2009. Values are mean \pm SE for 4 replicate enclosures (grazed) and control (ungrazed) plots. Stem density and height were determined in $1-\mathrm{m}^{2}$ plots and percent cover was determined in $100-\mathrm{m}^{2}$ plots. Arrows indicate the initiation of grazing periods; for cover (1c), the third grazing period falls between the last two measurement points. Results of repeated measures ANOVA are given within each panel for effects of grazing $(G)$, date $(D)$, and their interaction $(G \times D) .+P<0.1,{ }^{*} P<0.05,{ }^{* *} P<0.01,{ }^{* \star *} P<001$, and ${ }^{* \star * *} P<0.0001$. Asterisks above plotted points denote a significant grazing effect for that sampling date $(P<$ 0.05 , simple effect of grazing by date); P-value given for the last stem density comparison, where $P$ was between 0.05 and 0.1 . 
Figure 1.



\section{Figure 2}

Goat Grazing Impacts on Plant Diversity

Figure 2. Changes in plant species richness (a) and Shannon-Weaver diversity (b) throughout the experiment in response to rotational goat grazing. Values are means \pm SE for 4 replicate enclosures (grazed) and controls (ungrazed). Arrows indicate grazing period between sampling events; the third grazing period falls between the last two measurement points. An asterisk indicates a significant difference between grazed and ungrazed plots on a particular date $(P<0.05$, simple effect of grazing by date). Also presented are results of repeated measures ANOVA for effects of grazing $(G)$, date $(D)$, and their interaction $(G \times D)$. ${ }^{*} P<0.05$, ${ }^{* *} \mathrm{P}<0.01,{ }^{* * *} \mathrm{P}<001$, and ${ }^{* * * *} \mathrm{P}<0.0001$. 
Figure 2.

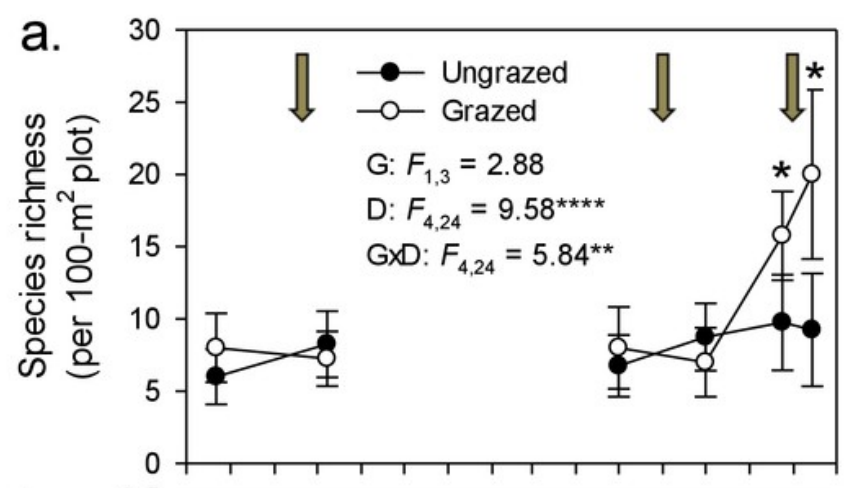

b.






\title{
Table 1 (on next page) \\ Management Considerations
}

\begin{abstract}
Based on our experimental findings, we find that livestock grazing for control of invasive plants holds great potential to reduce invasive plant biomass, increase plant diversity, and support livestock production. For effective control and to avoid negative impacts of overgrazing, we recommend:
\end{abstract}




\section{Table 1. Management Considerations}

Based on our experimental findings, we find that livestock grazing for control of invasive plants holds great potential to reduce invasive plant biomass, increase plant diversity, and support livestock production. For effective control and to avoid negative impacts of over-grazing, we recommend:

1. High-intensity, short-duration, rotational grazing. Grazers will be most effective in dense, monotypic stands that are common in the establishment and spread phases of invasions. Periods without grazers are likely very important in allowing native plants to establish (Fig. 2) and for the health of grazing livestock (Fig. 3b).

2. Small scale enclosures to concentrate feeding on the dominant, invasive plant (Fig. 4). In the case of Phragmites, the high digestible dry matter content of other wetland plant species (Fig. 3a) suggests that livestock permitted to graze freely might prefer other available plants.

3. The incorporation of grazing into a long-term management scheme. Grazing will not eradicate an invasive plant, but will release native plants from invasive dominance temporarily. Therefore, grazing may have to occur throughout many years, and possibly indefinitely.

4. Species-specific grazing windows. Time grazing events to suppress dominant plant invaders (i.e. early in the growing season) and limit 
clonal regrowth while providing adequate windows for native plants recolonization.

5. Landscape considerations. Grazing is unlikely to be effective in softsediment environments, such as low elevation marshes, where trampling effects may overwhelm native plant recovery. Grazers will be most effective on firm soils, such as those in the high marsh and at the upland marsh ecotone, where Phragmites invasions begin. 


\section{Figure 3}

\section{Marsh Plant Nutritional Value}

Figure 3. (A) Comparison of nutritional quality among six potential food plants in the cattlegrazed Dollard salt marshes, Netherlands. Figure shows the in vitro digestible dry-matter (DDM) content plotted with the crude-protein content (mean $\pm S D$ ) in young leaf tissue (five top leaves) during the grazing season (3rd decade of May - mid September). (B) Fall of forage quality (i.e., energy content) in leaf tissue of primary shoots of Phragmites in the Dollard salt marshes, Netherlands, during the grazing season based on the in vitro digestible dry-matter content in leaf tissue and compared with the level that cattle require for maintenance (after ARC 1980 \& Van Soest 1982). 
Figure 3

A)

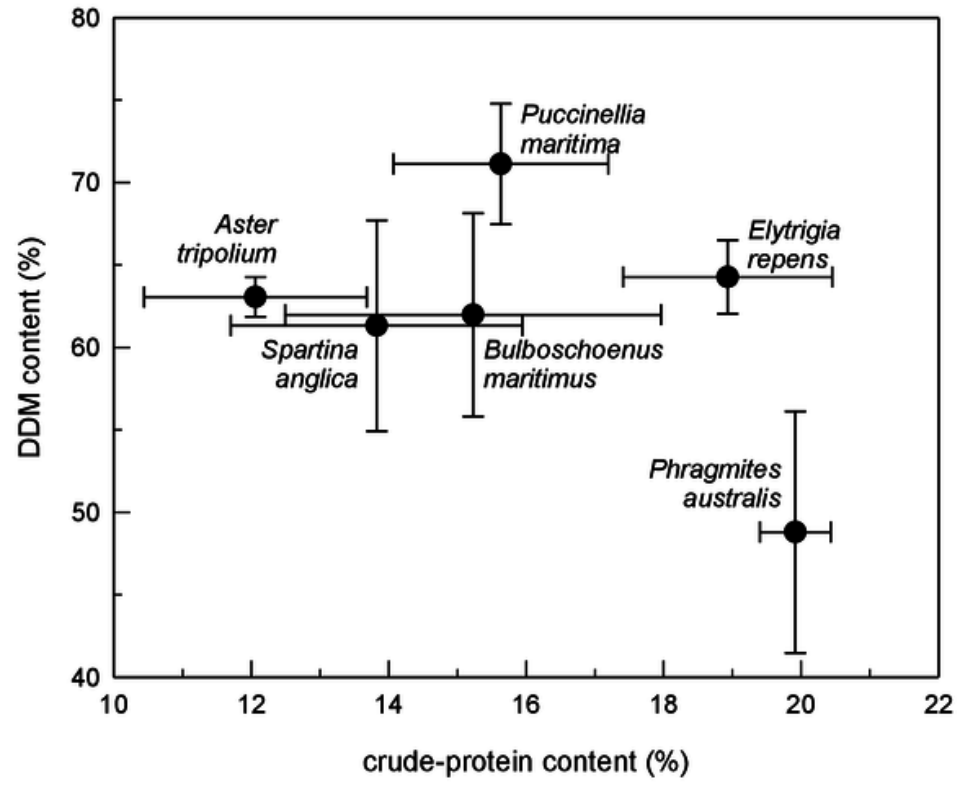

B)

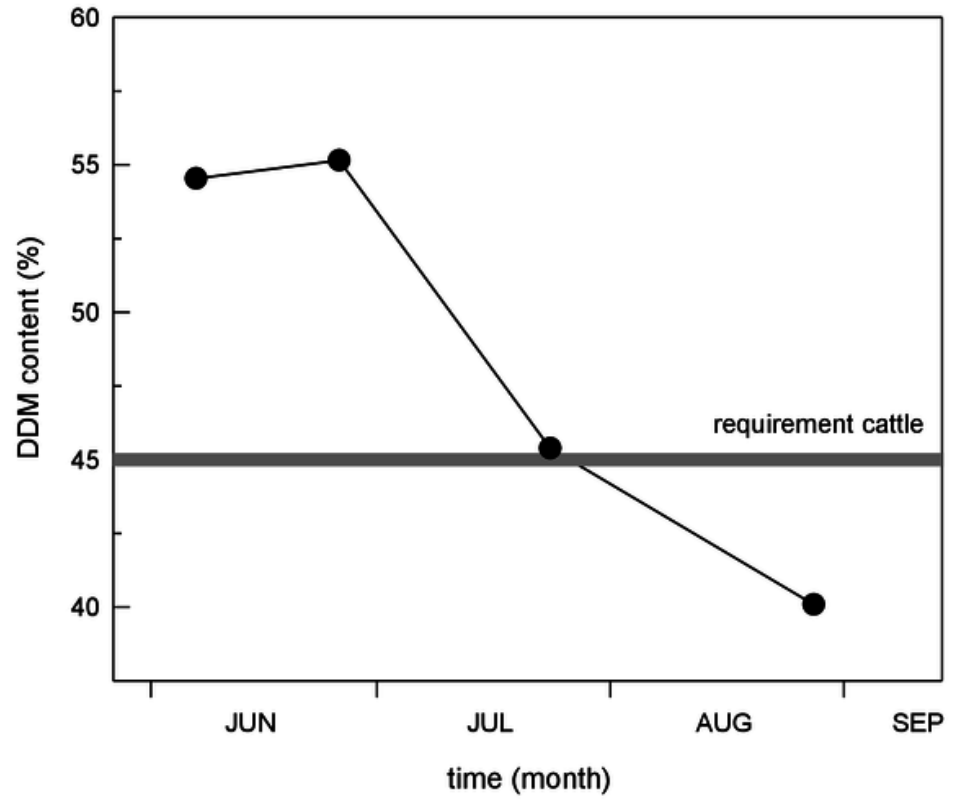




\section{Figure 4}

Images of Goat Grazing Impacts

Figure 4. Pictures of impacts of no-choice goat grazing in the Phragmites-dominated experimental wetland. 
Figure 4.
